\title{
СОВРЕМЕННЫЕ АСПЕКТЫ ОБЕСПЕЧЕНИЯ КАЧЕСТВА В НАУЧНО-ИССЛЕДОВАТЕЛЬСКОЙ ЛАБОРАТОРИИ ПО ФАРМАЦЕВТИЧЕСКОЙ РАЗРАБОТКЕ
}

\author{
Т.Н. Барыбина, М.Н. Макарова
}

Группа фармакокинетики, ЗАО «Санкт-Петербургский институт фармации», 188633, Россия, Ленинградская область, Всеволожский район, г.п. Кузьмоловский, ул. Заводская, д. 3 корп. 245.

DOI: 10.19163/MedChemRussia2021-2021-201

E-mail: barybina.tn@doclinika.ru

Основным документом, регламентирующим деятельность испытательных лабораторий, является ISO/IEC 17025 «Общие требования к компетентности испытательных и калибровочных лабораторий». Ключевым требованием стандарта является построение эффективной системы менеджмента качества лаборатории, которая обеспечивает получение точной и достоверной информации [1].

В докладе обсуждаются различные аспекты обеспечения качества в научно-исследовательской лаборатории по фармацевтической разработке. Исходя из специфики своей деятельности, такая лаборатория требует внедрения более адаптивной и гибкой системы менеджмента качества, которая предполагает наличие комплекта соответствующей внутренней документации, компетентного персонала, оснащенных лабораторных помещений, удовлетворяющих предписаниям воспроизводимых методик.

Разработка и тестирование лекарственных средств в лабораторных условиях должны осуществляться с помощью прошедших валидацию/верификацию стандартных методик с использованием лабораторного оборудования, прошедшего квалификацию, калибровку и поверку. На все лабораторное оборудование должны быть разработаны инструкции по его использованию. Для обеспечения корректной эксплуатации имеющегося оборудования должно проводится своевременное обучение персонала свежим версиям разработанных инструкций [2].

Таким образом, разработка и выполнение стандартных операционных процедур, разработка инструкций истандартных методик, ведение первичной документации, обеспечивающей прослеживаемость полученных в ходе исследования данных, - являются обязательным атрибутом при выполнении научно-исследовательских работ по фармацевтической разработке.

\section{Литература}

[1] Межгосударственный стандарт «Общие требования к компетентности испытательных и калибровочный лабораторий», ГOCT ISO/IEC 17025-2019.

[2] Д.В. Демченко, И.Н. Ампилогова, М.Н. Макарова. Разработка и регистрация лекарственных средств. 2020, Т.9, №4, 68-69.

$$
-201-
$$

